\title{
POSKYTOVATELÉ PLATEBNÍCH SLUŽEB MALÉHO ROZSAHU V MEZINÁRODNÍM OBCHODĚ
}

\author{
Rostislav Šárek
}

\section{Klíčová slova:}

poskytovatel platebních služeb malého rozsahu, platební služba, směna měny, přeshraniční platba

\section{Key words:}

payment service provider of small-scale, payment service, exchange of currency, cross-border payment

\begin{abstract}
Abstrakt
Tento článek se zabývá poskytovateli platebních služeb malého rozsahu, jež jsou v České republice subjekty podnikající na základě zákona o platebním styku. Podává analýzu praktického chování těchto subjektů s náhledem $\mathrm{k}$ definované teoretické základně, kterou představuje mimo jiné také aktuální legislativa. Potenciálními zákazníky těchto platebních služeb jsou především malé a střední podniky, podnikající i soukromé fyzické osoby. Ze široké škály platebních služeb se článek především zaměřuje na provádění bezhotovostních plateb do a ze zahraničí, které jsou spojeny s konverzí české nebo cizí měny. Empirická část textu je zaměřena na sledování dosažitelného směnného kurzu vybraného poskytovatele platebních služeb malého rozsahu a data dále srovnány s veřejně př́istupnými údaji vybrané platební instituce, a to především z důvodu prověření hypotézy, zda sledované subjekty nejsou jen zbytečným článkem celého řetězce služby. Dle zjištění praktických poznatků z činnosti těchto subjektů můžeme konstatovat, že platební instituce vystupuje vůči sledovaným poskytovatelům platebních služeb malého rozsahu ve dvojím unikátním postavení, poskytovatele služeb a zároveň konkurenčního subjektu.
\end{abstract}

\begin{abstract}
This article deals with the payment service provider of small-scale. These entities are authorized to provide payment services in the Czech Republic thanks to Payment System Act. This paper provides a practical analysis of the behavior of these entities with a preview of a defined theoretical base, which represents also the current legislation. Potential customers of these payment services are mainly small and medium enterprises, entrepreneurs and private individuals too. From a wide range of payment services this article mainly focuses on the implementation of cashless payments to and from abroad, which are associated with the conversion of a Czech or foreign currency. The empirical part is focused on monitoring of obtainable exchange rate by selected payment service provider of small-scale. Data were compared with publicly available data of selected payment institution in order to verify the hypothesis if these entities are not only unnecessary part of the whole chain. According to the findings of practical knowledge of these entities we can say that payment institutions act to payment service providers of small-scale in two unique positions, as service provider as well as a competitive entity.
\end{abstract}




\section{Úvod}

V rámci vývoje činnosti malých a středních podniků či podnikajících fyzických osob mohou nastat situace, že tyto subjekty potřebují v rámci svých ekonomických vztahů využít spolupráce se subjekty ze zahraničí. Z teoretického pohledu je př́činou takového chování především hledání a využití podnikatelských př́ležitostí nebo snaha o snižování nákladů, potažmo zvyšování výnosů a tím generování zisku jako požadovaného výsledku těchto aktivit.

Vzhledem ke geografické poloze Moravskoslezského kraje tak není překvapivé, že mnoho lokálních podnikatelských subjekti̊ si definovalo za svůj relevantní trh, na kterém hodlají působit, či již částečně nebo trvale působí, také území za hranicemi České republiky. Aktivně tak podnikají také na základě přeshraničních vztahů s geograficky i společensky blízkými sousedy z Polska, případně ze Slovenska. Z aktivit místních regionálních komor Hospodářské komory České republiky lze také vysledovat snahu o rozvoj těchto obchodních vztahů, což dokládá např́iklad zřízení a fungování kontaktních center česko-polské hospodářské spolupráce v Moravskoslezském kraji. ${ }^{1}$ Snaha o navázání přeshraničních obchodních vztahů je však patrná ve všech příhraničních krajích České republiky.

Zapojením mezinárodního prvku do obchodně-podnikatelských vztahů však logicky determinuje větší množství problematik, se kterými se musí malé a střední podniky, či podnikající fyzické osoby, ve své každodenní činnosti vypořádat. Kromě diferencí v oblastech technických, ekologických, kulturních, společenských, legislativních, hygienických a dalších ${ }^{2}$, tak tyto subjekty následně naráží na problematiku plynoucí z nutnosti převodů či přijímání peněžních prostředků v cizí měně jako protihodnoty za poskytnuté nebo přijaté zboží a služby. Vzhledem $\mathrm{k}$ často omezeným nákladovým možnostem na personální vybavení takových subjektů není možné, aby disponovali odborníky na každou z výše uvedených problematik, které mezinárodní interakce a spolupráce přinášejí.

Pokud se budeme nadále věnovat naznačenému okruhu subjektů a jejich vazeb na osoby za hranicemi České republiky, musíme v oblasti převodů peněžních prostředků počítat se dvěmi národními měnami sousedních států (EUR a PLN). Na řadu tak přichází nutnost zabezpečení řízení těchto peněžních transakcí s ohledem na minimalizaci rizik plynoucích z kurzových ztrát a dalších nákladů na tyto směnné operace s cílem dosažení co nejvýhodnější hodnoty směnného kurzu. Potřebu vynaložení úsilí ve snaze o minimalizaci tohoto rizika významně podporuje také odhad Ministerstva financí České republiky, podle něhož mohou úspory podniků vyplývající z omezení kurzového rizika dosáhnout až 1,4 procenta hrubého domácího produktu ročně. ${ }^{3}$ Sledované subjekty se mohou proti rizikům vyplývajícím z pohybu kurzů cizích měn zajistit u širokého spektra finančních institucí působících na trhu, jež pro tyto účely nabízejí hned několik produktů. ${ }^{4}$

\footnotetext{
${ }^{1}$ Kontaktní centrum Česko-Polské hospodářské spolupráce, Krajská hospodářská komora Moravskoslezského kraje, dostupné on-line na: http://www.khkmsk.cz/projekty/vytvoreni-site-kontaktnich-center-cesko-polskehospodarske-spoluprace/, staženo dne 2.2.2012.

${ }^{2}$ Více o problematice tzv. netarifních bariér mezinárodního obchodu např. ŠTRACH, P. Mezinárodní management, Praha: Grada Publishing, a.s., 2009, ISBN 978-80-247-2987-9.

${ }^{3}$ LACINA, L. a kol. Studie vlivu zavedení eura na ekonomiku $\check{C} R$, 2. upravené vydání o podněty z oponentního řízení, Bučovice: Martin Stř̌̌ž, 2008, MFČR, dostupné on-line na:

http://www.mfcr.cz/cps/rde/xbcr/mfcr/Studie_NKS_final_upravena_po_opnenture_31_08_20081.pdf, staženo dne 12.2.2012.

${ }^{4}$ Vzhledem k rozsahu a cíli tohoto článku však není účelné všechny finanční instituce, jejich produkty, př́ípadně externí a interní metody zajištění proti riziku plynoucímu z kolísání měnových kurzů dále analyzovat. Více o problematice např. ČERNOHLÁVKOVÁ, E., SATO, A., TAUŠER, J. Finanční strategie v mezinárodním
} 
Tento článek si především klade za cíl analyzovat praktickou činnost vybraného subjektu na finančním trhu, který prezentuje své aktivity jako alternativu ke klasickým bankovním službám v oblasti zabezpečování směny a převodů peněžních prostř̌edků v české nebo cizí měně. Jedná se o poskytovatele platebních služeb malého rozsahu, kteří podnikají na českém trhu na základě zákona o platebním styku (zákon č. 284/2009 Sb.). Součástí článku je také porovnání skutečně dosažených směnných kurzů poskytovatele platebních služeb malého rozsahu a platební instituce. Jedná se o subjekty, jež řadíme na finančním trhu mezi takové, které jsou mimo jiné schopny zabezpečit směnu cizí nebo české měny bezhotovostním způsobem. Vybraný subjekt je také významný tím, že je za určitých podmínek schopen nabídnout možnost poskytnutí jedné ze základních externích metod zajištění kurzového rizika, kterou představuje uzavření devizové pozice s využitím služeb peněžního trhu. ${ }^{5}$

\section{Legislativní základna jako významná součást teoretického východiska}

Zákon o platebním styku, který do českého právního řádu přinesl novou komplexní úpravu platebního styku, vstoupil v účinnost ke dni $1.11 .2009^{6}$. Zákon vznikl na základě transpozice tří evropských směrnic, konkrétně směrnice o platebních službách, směrnice o elektronických penězích a směrnice o neodvolatelnosti zúčtování. První dvě jmenované směrnice byly do českého právního řádu transponovány na základě plné harmonizace, což znamená, že se při jejich transpozici do českého právního řádu nebylo možné odchýlit od úpravy, která byla obsažena ve směrnicích, s výjimkou výslovně uvedených tzv. národních diskrecí. Cílem stanovení plně harmonizačního postupu bylo vytvoření identické právní úpravy ve všech členských státech Evropské unie. Vznik sledovaného poskytovatele platebních služeb malého rozsahu v České republice však pramení z využití možnosti národní diskrece. Její využití tak mělo přispět k lepší aplikaci vzhledem ke znalosti a specifikaci národních podmínek.

Regulovanými subjekty podle zákona o platebním styku jsou vedle poskytovatelů platebních služeb malého rozsahu také platební instituce, instituce elektronických peněž a vydavatelé elektronických peněz malého rozsahu. Tyto subjekty se tak staly na základě zákona o platebním styku dalšími oprávněnými osobami (vedle bank, spořitelních a úvěrních družstev, České národní banky a zahraničních institucí), které mohou poskytovat jako podnikání platební služby na území České republiky.

\section{Poskytovatelé platebních služeb malého rozsahu a platební instituce}

Poskytovatel platebních služeb malého rozsahu je dle zákona o platebním styku definován jako subjekt, který byl oprávněn poskytovat platební služby sám nebo prostřednictvím svých obchodních zástupců pouze tehdy, pokud měsíční průměr částek jím provedených platebních transakcí v České republice za posledních dvanáct měsíců nepřesahuje částku odpovídající 3 miliónům eur. ${ }^{8}$ Ze samotné zákonné definice tak vyplývá i nejpodstatnější omezení tohoto subjektu, které směřuje do oblasti limitní částky provedených platebních transakcí.

\footnotetext{
podnikání, ASPI, 2007, ISBN 978-80-7357-321-8.

5 Metoda spočívá v tzv. spárování budoucích finančních toků v cizích měnách. K otevřené devizové pozici, vyplývající např. z obchodní činnosti podnikatele, je otevřena nová pozice na peněžním trhu, která vytváří protisměrné finanční toky $\mathrm{v}$ dané cizí měně se stejným datem splatnosti a nominální výše transakce.

${ }^{6}$ Poslední novelizace uveřejněna ke dni 27.5.2011.

7 Směrnice Evropského parlamentu a Rady 2007/64/ES ze dne 13. listopadu 2007 o platebních službách na vnitřním trhu; Směrnice Evropského parlamentu a Rady 2009/110/ES ze dne 16. září 2009 o př́stupu k činnosti institucí elektronických peněz, o jejím výkonu a o obezřetnostním dohledu nad touto činností; Směrnice Evropského parlamentu a Rady, kterou se mění směrnice 98/26/ES o neodvolatelnosti zúčtování v platebních systémech a v systémech vypořádání obchodů s cennými papíry.

${ }^{8}$ Viz $§ 36$ odst. 2 zákona o platebním styku.
} 
Poskytovatel platebních služeb malého rozsahu nesmí v rámci provedených platebních transakcí za posledních dvanáct měsíců přesáhnout souhrnnou částku 36 miliónů eur, tedy zhruba 900 miliónů korun českých.

K zahájení poskytování platebních služeb tomuto subjektu přitom postačuje získání registrace u České národní banky, které je vedeno v rámci posouzení žádosti bez vedení správního řízení. ${ }^{9}$ Podmínky registrace poskytovatele platebních služeb malého rozsahu zahrnují mimo jiné bezúhonnost zúčastněných fyzických osob, zajištění ochrany peněžních prostředků svěřených k provádění platebních transakcí či předložení obchodního plánu na 12 měsíců. Hlavní rozdíl mezi platební institucí a poskytovatelem platebních služeb malého rozsahu tak je $\mathrm{v}$ přísnějších požadavcích, které jsou kladeny na platební instituce, ale především ve skutečnosti, že platební instituce získává tzv. jednotné povolení pro trh Evropského hospodářského prostoru k poskytování platebních služeb bez limitního omezení hodnoty platebních transakcí.

\section{Limit a vykazování provedených platebních transakcí}

Významným omezením platebních institucí malého rozsahu je výše popsaný limit provedených platebních transakcí. Z pohledu uživatele těchto služeb je daná problematika méně relevantní, jelikož uživatel bude především sledovat poměr kvality a ceny provedené služby, avšak v krajních případech může mít limit pro provedení platebních transakcí v konečném důsledku vliv na nepřijetí požadavku k provedení platební transakce (směny a převodu cizí měny ze strany poskytovatele platební služby). To může ovlivnit například včasné splnění závazků podnikatelů, jež vyplynuly z obchodního vztahu se zahraničním subjektem. Poskytovatel platebních služeb malého rozsahu však musí jednoznačně v interních normách stanovit, jakým způsobem bude prakticky zabezpečeno, že nedojde k dosažení limitu provedených platebních transakcí.

Obvyklou simplifikací (avšak nejen zjednodušující, ale i mylnou praktikou) s níž se lze u těchto subjektů setkat, je pevné zakotvení maximálního měsíčního limitu, vztahujícího se k částce 3 miliónů eur. Těsně před jeho dosažením (např̀. od hodnoty 2,8 mil. eur) jsou již všechny následně přijaté požadavky k provedení platebních transakcí kompetentní osobou jednotlivě vyhodnocovány a schvalovány tak, aby $\mathrm{v}$ žádném měsíci nedošlo $\mathrm{k}$ překročení částky 3 miliónů eur. Pevně stanovená měsíční hranice pro platební transakce je v případech, kdy v některém z posledních dvanácti měsíců nedojde $\mathrm{k}$ dosažení tohoto limitu, zbytečně př́sná a $\mathrm{v}$ důsledku může omezovat podnikatelskou činnost platební instituce malého rozsahu s vlivem na naplnění požadavků svých klientů.

Takto špatně nastavené interní směrnice však mohou mít své důsledky při interní či externí kontrolní činnosti. Pokud by došlo v rámci jednoho z měsíců k překročení interně stanovené hranice pro částku provedených platebních transakcí, dopustil by se tento subjekt vědomého porušení jedné $\mathrm{z}$ interních norem, která je $\mathrm{v}$ tomto př́ípadě povinnou součástí žádosti o registraci k činnosti platební instituce malého rozsahu. Neoznámení změn v této skutečnosti je považováno za správní delikt, za který může být uložena pokuta až do výše 10 mil. Kč. Pokud by však provedení platební transakce ve skutečnosti zabraňoval zákonný limit, muselo by ze strany platební instituce malého rozsahu dojít k odmítnutí jejího provedení. Za porušení

\footnotetext{
${ }^{9}$ Zápis do registru u ČNB tak představuje tzv. konstitutivní účinek. Na rozdíl od platební instituce, jejíž zápis u ČNB představuje tzv. deklaratorní účinek.
} 
pravidla limitu provedených platebních transakcí totiž dle současné právní úpravy poskytovateli platebních služeb malého rozsahu hrozí pokuta až do výše 50 mil. Kč.

Za samostatnou problematiku především z pohledu poskytovatelů platebních služeb malého rozsahu bychom mohli označit komplikované a nejasně definované zákonné požadavky pro sledování a vykazování částek provedených platebních transakcí. V dané věci je tř̌eba vždy vycházet ze zákonné definice platební transakce ${ }^{10}$, kterou se rozumí vložení peněžních prostř̌edků na platební účet, výběr peněžních prostředků z platebního účtu nebo převod peněžních prostředků. Hlavním dělícím znakem pro sledování objemu skutečně provedených platebních transakcí je tak využití platebního účtu uživatele u daného poskytovatele platební služby ${ }^{11}$. Naznačená problematika tak úzce souvisí s jednotlivými platebními službami, které jsou hlavním předmětem žádosti o registraci poskytovatelů platebních služeb malého rozsahu. Znalostí obsahu konkrétní registrované platební služby by tak měli disponovat také samotní uživatelé platebních služeb, nebot' je v zájmu obou zúčastněných stran, aby služba zákazníkovi byla provedena subjektem, který $\mathrm{k}$ dané činnosti disponuje prŕslušným oprávněním.

\section{Registr České národní banky}

Skutečnost, zda požadovanou platební službou disponuje či může disponovat vybraný poskytovatel platebních služeb malého rozsahu, je možné ověřit v rámci Seznamu regulovaných a registrovaných subjektů finančního trhu, který je zveřejněn a průběžně aktualizován na internetových stránkách České národní banky. Seznam obsahuje kromě informací o povolených činnostech (výčet konkrétních povolených platebních služeb) také informace o dalších vazbách v rámci působení subjektu na finančním trhu, kontaktní informace, webové odkazy a další relevantní informace o subjektu, které mohou sloužit jako případné vodítko při individuálním výběru vhodného poskytovatele. Seznam registrovaných subjektů České národní banky tak představuje nástroj, jež kromě své hlavní informační funkce může sloužit jako opora budoucích potenciálních uživatelů při výběru těchto služeb. Zahájení výběru jednoho z takto podnikajících subjektů by tak mělo začínat hledáním v Seznamu regulovaných a registrovaných subjektů finančního trhu. Jedná se však o základní vodítko, které poskytuje uživateli jistou míru garance při poskytování služeb, avšak dostupnost konkrétních požadovaných služeb je vždy nutné ověřit na jednom z dalších výše uvedených pramenů informací, tedy přímo u konkrétního poskytovatele.

\section{Registrované platební služby}

Bezhotovostním obchodem s cizí měnou se dle zákona o platebním styku rozumí nákup nebo prodej peněžních prostředků v české nebo cizí měně za peněžní prostředky v jiné měně, jestliže jsou peněžní prostředky od uživatele přijaty nebo uživateli dány $\mathrm{k}$ dispozici bezhotovostně. Tato úprava byla beze zbytku přijata $\mathrm{z}$ devizového zákona ${ }^{12}$, který před účinností současného zákona o platebním styku plně upravoval činnosti na základě udělené devizové licence k provádění obchodů s devizovými hodnotami a k poskytování peněžních služeb.

Pokud podnikatelé budou vyhledávat v rámci Seznamu regulovaných a registrovaných subjekti̊ finančního trhu poskytovatele platebních služeb malého rozsahu, kteří pro jejich

\footnotetext{
${ }^{10}$ Viz $§ 3$ zákona o platebním styku.

${ }^{11} \mathrm{~V}$ daném př́ípadě by se jednalo o platební účet podnikatele u poskytovatele platebních služeb malého rozsahu.

12 Zákon č. 219/1995 Sb., devizový zákon, ve znění účinném do 31.10.2009.
} 
účely budou schopni zabezpečit právě bezhotovostní obchody s cizí měnou a př́ípadné další platební služby, v rámci povolených činností jednotlivých subjektů budou vyhledávat platební službu, obsahující převod peněžních prostředků. Bezhotovostní obchody s cizí měnou totiž spadají do kategorie platebních služeb, při nichž dochází k převodu peněžních prostředků.

Ze škály existujících platebních služeb dle ustanovení § 3 zákona o platebním styku se v požadovaném případě bude nejčastěji jednat o platební službu podle písm. c), tedy provedení převodu peněžních prostředků z platebního účtu, k němuž dává platební př́ikaz plátce, př́ijemce, nebo plátce prostř̌ednictvím př́ijemce, jestliže poskytovatel neposkytuje uživateli převáděné peněžní prostředky jako úvěr. ${ }^{13}$ Tato platební služba se tak bude objevovat $\mathrm{v}$ povolených činnostech těch poskytovatelů platebních služeb malého rozsahu, kteří v rámci své činnosti počítají s vedením platebních účtů svých zákazníků.

Druhou, v tomto kontextu možnou registrovanou platební službou, která povoluje poskytovatelům platebních služeb malého rozsahu poskytovat provedení převodu peněžních prostředků, je platební služba podle ustanovení $\S 3$ písm. f) zákona o platebním styku, tedy provedení převodu peněžních prostředků, při němž plátce ani př́ijemce nevyužívají platební účet u poskytovatele plátce. Povolením této platební služby typicky disponují tzv. remiteři, což jsou subjekty s celosvětovou sítí poboček, jejichž předmětem podnikání je zasílání peněžních prostř̌edků, obsahující většinou v rámci této peněžní transakce také směnu měn ${ }^{14}$.

Dostupnost požadované služby u poskytovatele, jejíž součástí bude obchod s devizami a provedení peněžních služeb, však pouhým vyhledáním jedné (či obou) výše uvedených platebních služeb v Seznamu regulovaných a registrovaných subjektů, není zaručena. Můžeme tedy říci, že jedna z výše uvedených povolených platebních služeb může být zapsána do Seznamu regulovaných a registrovaných subjektů finančního trhu, což ovšem automaticky vždy neznamená, že poskytovatel platebních služeb malého rozsahu bude poskytovat směny cizích měn a převody peněžních prostředků do zahraničí. Př́́kladem mohou být společnosti, které poskytují systém umožňující provedení plateb pomocí mobilního telefonu, a to př̀i nákupech zboží či služeb pomocí webu. ${ }^{15}$

Ke dni 21. 2. 2012 obsahoval Seznam regulovaných a registrovaných subjektů finančního trhu 56 záznamů o poskytovatelích platebních služeb malého rozsahu. Na základě analýzy informací o skutečně poskytovaných službách bylo zjištěno, že 23 těchto registrovaných subjektů se zabývá prováděním platebního styku ve vztahu k zahraničí nebo bezhotovostními obchody s cizí měnou. Většina z těchto subjektů byla v minulosti držiteli devizové licence k provádění obchodů s devizovými hodnotami a k poskytování peněžních služeb. Významný podíl z počtu těchto subjektů se dále zabývá směnárenskou činností, tedy poskytování služeb třetím osobám, jejichž předmětem je nákup nebo prodej bankovek, mincí nebo šeků v cizí nebo české měně za bankovky, mince nebo šeky v jiné měně ${ }^{16}$.

\section{Skutečný rozsah služeb a podmínky provedení obchodu}

Služeb těchto vybraných poskytovatelů platebních služeb malého rozsahu využívají především subjekty, které hradí své cizoměnové závazky nebo inkasují své pohledávky z tuzemského

\footnotetext{
${ }^{13} \mathrm{~V}$ případě, že by klientům bylo umožněno čerpání úvěru, jednalo by se o platební službu podle $\S 3$ písm. d) zákona o platebním styku.

${ }^{14}$ Typicky např. společnosti Wester Union, MoneyGram apod.

${ }^{15}$ Počet registrovaných poskytovatelů tohoto druhu platebních služeb nabývá na významnosti.

${ }^{16}$ Viz definice směnárenské činnosti dle ustanovení § 1 písm. 1) zákona č. 219/1995 Sb., devizový zákon.
} 
nebo zahraničního platebního styku. Klienti mají možnost využívat služeb trvale na základě obecné rámcové smlouvy s poskytovatelem platebních služeb malého rozsahu. Někteří z poskytovatelů umožňují také provést pouze jednorázovou platební transakci. Součástí služby je ve většině případů vedle provedení úhrad do zahraničí a přijímání úhrad ze zahraničí, také samotné provedení směnného obchodu, tedy konverze české měny na cizí měnu, cizí měny na českou měnu či konverze dvou cizích měn.

Aby mohlo ve stanovený čas dojít k provedení směnného obchodu, je nutné, aby klienti bezprostředně po sjednání všech nezbytných náležitostí obchodu bezhotovostně odeslali příslušnou peněžní částku na bankovní účet poskytovatele platebních služeb malého rozsahu. Toto sjednání probíhá u většiny poskytovatelů těchto služeb prostřednictvím telefonního hovoru a dojednané podmínky obchodu jsou následně zaneseny do písemného potvrzení o sjednání obchodu a nejčastěji v elektronické podobě odeslány klientovi. Někteří z poskytovatelů ještě následně požadují po klientech provedení odsouhlasení dohodnutých parametrů obchodu formou podepsání potvrzení (tzv. konfirmace) a zpětného zaslání na poskytovatele. Za nezbytné náležitosti obchodu, které jsou již předmětem jednání v rámci telefonního rozhovoru, můžeme považovat druh a množství měny, směnný kurz, datum a způsob vypořádání obchodu.

Základním sledovaným parametrem těchto obchodů je pro klienta bezesporu směnný kurz, který poskytovatel dokáže klientovi nabídnout. Další náklady spojené s provedením směnného obchodu, které by musel klient sledovat a porovnávat v rámci tržní nabídky v podstatě neexistují, nebot' z provedeného šetření vyplynulo, že poskytovatelé služeb automaticky začleňují své nákladové položky a případný zisk již do hodnoty směnného kurzu. Někteří poskytovatelé jsou dále schopni zajistit pro klienty doplňkové služby, jež mohou být spojeny např́iklad s automatickým sledováním a oznámením požadovaného hodnoty směného kurzu, který byl klientem předem stanoven ve formě poptávkového pokynu.

\section{Poskytování platebních služeb ve většině případů znamená jejich zprostřredkování}

Vzhledem ke skutečnosti, že na poskytovatele platebních služeb malého rozsahu není kladen požadavek na základní kapitál ${ }^{17}$, nelze ani očekávat, že tyto subjekty budou dostatečně finančně zabezpečeny pro provádění všech obchodů z vlastních držených zdrojů a zároveň v požadované měnové struktuře. Na základě praktických poznatků fungování vnitřních mechanismů poskytovatelů platebních služeb malého rozsahu lze konstatovat, že požadované peněžní prostředky většiny bezhotovostních obchodů s cizí měnou se dále projevují na objemech transakcí platebních institucí. Bezprostředně po sjednání parametrů obchodu s klientem tak poskytovatelé platebních služeb malého rozsahu ve většině případů (prakticky vždy u transakcí ve vyšších nominálních hodnotách) zadávají totožný požadavek na trhu, tedy u jednoho ze svých obchodních partnerů, u kterých si zajišt'ují získávání požadované měnové struktury peněžních prostředků. Směnný kurz nabízený klientovi tak do jisté míry automaticky odráží nabídku těchto spolupracujících obchodních partnerů. Dle zjištění jsou těmito subjekty v mnoha případech platební instituce, které podnikají také na základě zákona o platebním styku, a jež nejsou omezeny žádným limitem provedených platebních transakcí.

\footnotetext{
17 Pro držitele devizových licencí k bezhotovostním obchodům s cizí měnou (tj. ve většině případů dnešní poskytovatelé platebních služeb malého rozsahu) byla přitom v minulosti určena podmínka výše splaceného základního kapitálu v hodnotě nejméně 10 mil. Kč.
} 


\section{Zbytečný článek řetězce?}

Z výše uvedeného tvrzení by však vyplývalo, že by se podnikatelé z podstaty věci měli vyhnout obchodování s cizí měnou s poskytovateli platebních služeb malého rozsahu a navázat spolupráci př́ímo s platebními institucemi. Pokud budeme vycházet z předpokladů, že a) poskytovatelé platebních služeb malého rozsahu vždy obstarávají klientem požadovanou hodnotu a strukturu cizí měny u platební instituce (tzv. zrcadlový pokyn); b) poskytovatelé platebních služeb realizují zisk z každé klientovi provedené směny; c) platební instituce přistupují ke všem svým klientům při stanovení směnného kurzu jednotně; d) směnný kurz je jedinou a rozhodující položkou, tedy že další náklady klienta ve formě např. poplatků z realizace směnného obchodu neplynou, pak realizovaný zisk poskytovatele platebních služeb malého rozsahu by se u takových směnných obchodů generoval vždy na úkor zákazníků. V takových prrípadech bychom poskytovatele platebních služeb malého rozsahu považovali za nadbytečný článek řetězce mezi platební institucí a klientem. ${ }^{18}$

Tato hypotéza se tak stala předmětem empirického šetření, provedeného u poskytovatele platebních služeb malého rozsahu (PPSMR) a platební instituce (PI), o niž bylo předem známo, že vystupuje ve vztahu k vybranému poskytovateli platebních služeb malého rozsahu jako spolupracující subjekt, který zabezpečuje dodání požadovaného množství a struktury cizí měny. ${ }^{19}$ Zjištěné výsledky ukazují následující tabulky. Uvedené hodnoty směnných kurzů v tabulkách jsou vždy chápány z pohledu klienta.

Tabulka č. 1 - hodnoty směnných kurzů pro prodej cizí měny

\begin{tabular}{|c|c|c|c|}
\hline Datum & Měna & PPSMR & PI max \\
\hline 2.6 .2011 & EUR & 24,420 & 24,456 \\
\hline 7.6 .2011 & GBP & 26,900 & 27,109 \\
\hline 13.6 .2011 & GBP & 27,150 & 27,300 \\
\hline 21.6 .2011 & EUR & 24,180 & 24,126 \\
\hline 15.8 .2011 & EUR & 24,220 & 24,218 \\
\hline 18.8 .2011 & EUR & 24,270 & 24,328 \\
\hline 1.9 .2011 & USD & 16,600 & 16,862 \\
\hline 18.10 .2011 & EUR & 24,650 & 24,807 \\
\hline 18.10 .2011 & EUR & 24,800 & 24,807 \\
\hline 10.11 .2011 & EUR & 25,470 & 25,505 \\
\hline 11.11 .2011 & EUR & 25,600 & 25,597 \\
\hline 8.12 .2011 & EUR & 25,280 & 25,462 \\
\hline & \multicolumn{3}{|c}{ Zdroj: vlastní }
\end{tabular}

Tabulka č. 2 - hodnoty směnných kurzů pro nákup cizí měny

\begin{tabular}{|c|c|c|c|}
\hline Datum & Měna & PPSMR & $P$ max \\
\hline 10.6 .2011 & EUR & 24,200 & 24,213 \\
\hline 4.7 .2011 & EUR & 24,340 & 24,329 \\
\hline 12.7 .2011 & EUR & 24,350 & 24,329 \\
\hline 20.7 .2011 & USD & 17,300 & 17,290 \\
\hline 29.7 .2011 & USD & 17,150 & 16,912 \\
\hline 31.10 .2011 & EUR & $\mathbf{2 4 , 8 3 0}$ & 24,796 \\
\hline 21.11 .2011 & EUR & $\mathbf{2 5 , 7 1 0}$ & 25,595 \\
\hline 7.12 .2011 & USD & 19,100 & 18,825 \\
\hline
\end{tabular}

Zdroj: vlastní

\footnotetext{
${ }^{18}$ Každý autor usiluje o to, aby se jeho hypotézy přeměnily v systém názorů a poznatků zkoumaného jevu či procesu, tedy v teorii, kterou lze spolu s empirickými poznatky aplikovat ve výuce na vysoké škole.

${ }^{19}$ Anonymita subjektů vyplývá z povinnosti autora zachovávat obchodní zájmy konkrétních sledovaných společností.
} 
Vzorek 20 konkrétních sledování směnných kurzů poskytovatele platebních služeb malého rozsahu spadal do období od června do prosince roku 2011 a vycházel ze skutečných hodnot, za nichž byly realizovány směnné obchody. Hodnota směnného kurzu se v čase vlivem tržních procesů značně vyvíjí a poskytovatelé platebních služeb malého rozsahu při sjednávání spotového směnného kurzu s klientem musí vždy reagovat na aktuální vývoj trhu a to především s ohledem na nutnost případného obstarání požadované měny na trhu. Pro sledování daného vývoje proto nejčastěji využívají on-line aplikací finančních a platebních institucí s údaji o aktuálních hodnotách směnných kurzů měn. Ty pak slouží jako aktuální referenční hodnoty, od kterých se odvíjí konkrétní spotové nabídky hodnot směnných kurzů, které jsou následně předkládány jako nabídka klientům.

Tabulky dále obsahují hodnoty směnných kurzů pro dané dny u vybrané platební instituce, u nichž bylo známo, že s daným poskytovatelem platebních služeb obchoduje. Tyto hodnoty u platební instituce byly převzaty $\mathrm{z}$ dostupné historie směnných kurzů z webových stránek platební instituce. V tabulkách uvedené hodnoty odpovídá nejvýhodnějšímu směnnému kurzu daného dne z pohledu klienta.

Konkrétní požadavky na směnu se v rámci vzorku týkaly tří cizích měn. Byly zadávány a realizovány požadavky jak pro nákup, tak prodej cizích měn. Vzorek obsahoval 12 požadavků pro prodej cizí měny a 8 požadavků pro nákup cizí měny. V 9 případech prodejní požadavek směřoval vůči měně EUR, ve dvou k prodeji GBP a v jednom k prodeji USD. Dále vzorek obsahoval 8 požadavků pro nákup cizí měny, z čehož 5 sledování se týkalo měny EUR, a 3 sledování byly vůči měně USD. Délka sledování a frekvence směnných obchodů byla zvolena s ohledem na běžné potřeby výše uvedeného segmentu cílových zákazníků.

Přesto že se jednalo o subjekty, které spolu s cizí měnou obchodují na základě smluvní spolupráce, nelze jednoznačně tvrdit, že platební instituce nabízí koncovému zákazníkovi vždy lepší směnný kurz oproti poskytovateli platebních služeb malého rozsahu. K pozorování je dále vhodné doplnit, že objem hodnoty požadované směny se v jednotlivých případech lišil. Tyto rozdílné hodnoty požadovaného objemu však nebyly v rámci pozorování rozhodující, nebot' oba vybraní poskytovatelé služeb neměli veřejně př́stupnou informaci o stanovení minimální ani maximální výše objemu směny, ani objemová pásma, s lišícími se hodnotami směnných kurzů.

Je nutné zdůraznit, že hodnoty směnných kurzů platební instituce, které jsou uvedeny v tabulkách, odpovídají z pohledu klienta nejvýhodnějšímu směnnému kurzu pro daný den (v tabulkách označeno jako PI max). Z této skutečnosti je dále dovoditelné, že je jen málo pravděpodobné, aby byl tento kurz platební institucí s běžným klientem vždy sjednán a realizován. U čtyř sledování bylo i přes vše výše uvedené zjištěno, že výhodnější směnný kurz nabídl a realizoval pro koncového zákazníka poskytovatel platebních služeb malého rozsahu. Na základě provedeného sledování můžeme konstatovat, že se hypotézu nepodařilo potvrdit.

Následným sledováním detailních podkladů $\mathrm{k}$ jednotlivým obchodům bylo zjištěno, že předpoklad jednotného prrístupu platební instituce vůči všem svým klientům nebyl naplněn, což se ukázalo ve sledování jako klíčové. Ověřením dalších předpokladů na základě analýzy skutečně realizovaných hodnot se nepodařilo prokázat chybně zvoleného přístupu. Ačkoliv platební instituce zveřejňuje nabídku směnných kurzů pomocí svých webových stránek v online režimu, na základě skutečně provedených zrcadlových obchodů s cizí nebo českou 
měnou byla potvrzena vyšší vyjednávací schopnost poskytovatele platebních služeb malého rozsahu z pozice klienta platební instituce. Hodnoty skutečně realizovaných směnných kurzů byly pro poskytovatele platebních služeb malého rozsahu z pozice klienta ve většině případů výhodnější, než uvedený nejvýhodnější směnný kurz platební instituce pro daný den. Toto zjištění se týkalo všech čtyřech př́ípadů, ve kterých poskytovatel platebních služeb malého rozsahu realizoval obchod s klientem za výhodnějších podmínek oproti nejvýhodnější nabídce platební instituce pro daný den. Skutečnost, že se ve čtyřech případech podařilo poskytovateli platebních služeb malého rozsahu realizovat pro klienta výhodnější hodnotu směnného kurzu, je do jisté míry spojena s dosaženou tržní pozicí tohoto subjektu, který má svůj základ v hodnotách objemu spolupráce s platební institucí.

\section{Závěr}

$\mathrm{Na}$ základě provedeného šetření s hodnotami směnných kurzů nemůžeme tvrdit, že u poskytovatelů platebních služeb malého rozsahu není možné dosáhnout výhodnějšího směnného kurzu oproti platební instituci, která s poskytovatelem působí jako spolupracující subjekt. Neznalost skutečných obchodních vazeb mezi jednotlivými poskytovateli služby nepředstavuje pro klienty žádné reálné znevýhodnění. Klienti totiž budou př̀i výběru svého poskytovatele platební služby vybírat především na základě skutečně dosažitelných hodnot směnných kurzů. Z analýz nákladových podmínek poskytovatelů těchto služeb se ukázalo, že pro klienty neznamenají žádná otevřená či skrytá rizika. Poměrně silné konkurenční prostředí dokázalo zapříčinit, že u poskytovatelů platebních služeb malého rozsahu (ale i u platebních institucí) neexistují poplatky spojené s konverzemi české nebo cizí měny. Obdobně je tomu v široké oblasti prrípadného vedení platebního účtu klienta, ve které poskytovatelé těchto platebních služeb jsou schopni získat mnoho klientů na úkor některých velkých spořitelních a úvěrových společností, které nabízejí zřízení a vedení devizových účtů za cenu nemalých poplatkových nákladů. Nákladové položky a případná zisková marže z operací je poskytovateli platebních služeb malého rozsahu již začleněna do hodnoty nabízeného směnného kurzu.

Malé a střední podniky, podnikatelé či fyzické osoby by tak při potřebě využití těchto platebních služeb měli věnovat čas analýze dostupné nabídky poskytovatelů platebních služeb malého rozsahu a zkusit oslovit se svými požadavky tyto subjekty. Ne každý poskytovatel platebních služeb malého rozsahu, který byl zapsán do Seznamu regulovaných a registrovaných subjektů u České národní banky, však dokáže zabezpečit sledované bezhotovostní obchody s cizí měnou a další platební služby, spojené s poukazováním peněž do a ze zahraničí. Registr tak může alespoň sloužit jako základní vodítko pro zorientování se v aktuální tržní nabídce.

Závěrem uved'me, že především s příchodem možnosti vedení platebních účtů klientů u těchto subjektů prokazatelně došlo $\mathrm{k}$ nárůstu rizik spojených se správou finančních prostředků svěřených $\mathrm{k}$ provádění transakcí. Tuto skutečnost by měli aktivní či potenciální uživatelé těchto platebních služeb začlenit při svých rozhodováních mezi reálné rizikové faktory. $Z$ výše uvedeného také vyplývá potřeba zvýšení aktivity v oblasti kontroly těchto subjektů ze strany dohledového orgánu, což můžeme považovat za významný prvek pro postupné zvyšování důvěry v tyto subjekty a tím k celému finančnímu trhu. 


\section{Literatura:}

[1] BALABAN, D. New Players Could Vie With Banks In Pan-European Payments Business, Cards \& Payments, May 2009, Vol. 22 Issue 5, p14-18.

[2] ČERNOHLÁVKOVÁ, E., SATO, A., TAUŠER, J. Finanční strategie v mezinárodním podnikání, ASPI, 2007, ISBN 978-80-7357-321-8.

[3] ŠTRACH, P. Mezinárodní management, Praha: Grada Publishing, a.s., 2009, ISBN 97880-247-2987-9.

[4] LACINA, L. a kol. Studie vlivu zavedení eura na ekonomiku $\check{C} R, 2$. upravené vydání o podněty z oponentního řízení, Bučovice: Martin Strřǐž, 2008, MFČR, dostupné on-line na: http://www.mfcr.cz/cps/rde/xbcr/mfcr/Studie_NKS_final_upravena_po_opnenture_31_08 _20081.pdf, staženo dne 12.2.2012.

[5] Krajská hospodářská komora Moravskoslezského kraje, Kontaktní centrum Česko-Polské hospodářské spolupráce, dostupné on-line na: http://www.khkmsk.cz/projekty/vytvorenisite-kontaktnich-center-cesko-polske-hospodarske-spoluprace/, staženo dne 2.2.2012.

[6] Směrnice Evropského parlamentu a Rady 2007/64/ES ze dne 13. listopadu 2007 o platebních službách na vnitřním trhu.

[7] Směrnice Evropského parlamentu a Rady 2009/110/ES ze dne 16. záŕí 2009 o prrístupu k činnosti institucí elektronických peněz, o jejím výkonu a o obezřetnostním dohledu nad touto činností.

[8] Směrnice Evropského parlamentu a Rady, kterou se mění směrnice 98/26/ES o neodvolatelnosti zúčtování $\mathrm{v}$ platebních systémech a v systémech vypořádání obchodů $\mathrm{s}$ cennými papíry.

[9] Zákon č. 284/2009 Sb., o platebním styku.

[10]Zákon č. 219/1995 Sb., devizový zákon.

\section{JEL F31, G28}

\section{Ing. Rostislav Šárek}

doktorant v kombinované formě studia

Slezská univerzita v Opavě

Obchodně podnikatelská fakulta

Univerzitní náměstí 1934/3

73340 Karviná

sarek.rostislav@gmail.com 